911.52:551.312.2(477.83)

\author{
. л жко, . іпт ч \\ ьвівський н ціон льний університет імені в н \\ вул. . орошенк , 41, м. ввів, 79000, кр їн
}

ро н лізов но з п си торфових ресурсів ьвівської обл., т кож основні морфометричні $\mathrm{x}$ р ктеристики торфів. исвітлено дин міку обсягів видобув ння торфу в меж х н йбільших торфовищ обл сті. зн чено головні проблеми, пов'яз ні з видобув нням торфу, т з пропонов но шляхи їхнього вирішення.

лючові слов : торф, торфове родовище, відпр цьов ні торфовищ, рен тур ліз ція торфовищ.

орфові родовищ 3 ост нні 30-40 років н території ьвівської обл. зн чно змінили свій первісний вигляд. природному ст ні їх пр ктично не 3 лишилось. они були осушені, бо ч стин з них використ н для добув ння торфу. ьогодні торф добув ють у незн чній кількості через нерент бельність і зменшення попиту. роте з цік влення торфом як природним ресурсом почин є відновлюв тись. огляду н це для рціон льного використ ння торфів потрібно дет льно про н лізув ти ре льні з п си торфів в обл сті й з пропонув ти шляхи їх використ ння й перероблення.

орф як добриво широко використовув ли у післявоєнні роки, зокрем , у поліському регіоні. н чне поширення сл бкокислих і сл бколужних торфів, великий вміст зоту, дост тній - в пн і нерідко фосфору х р ктеризують торф як цілком прид тний для виготовлення добрив. ослідження т використ ння торфових родовищ поч лося близько двохсот років тому, їхнє н укове вивчення - у другій половині ст. окрем , дослідження рослинності т геогр фії поширення боліт висвітлено у пр цях 3 болотозн вств у . нфільєв, . октуровського і . ук чов . поч тку ст. опубліков но пр ці, присвячені природі олісся, торф'яним болот м, їхній стр тигр фії т геогр фічному поширенню. ьогодні н йбільший обсяг інформ ції щодо використ ння й суч сного ст ну торфових ресурсів ьвівської обл. є в м тері л х обліку івнічного держ вного регіон льного геологічного підприємств івнічгеологія (м. иїв) і крторф (м. иїв).

б'єктом н шого дослідження є торфові ресурси ьвівської обл., метою - оцінк суч сних з п сів торфу в меж х торфовищ обл сті, н ліз ст ну використ ння цих ресурсів і виокремлення головних проблем, пов'яз них з видобув нням торфу.

орфове родовище - це 3 торфов н ділянк суходолу площею пон д 1 г і потужністю ш ру торфу пон д 0,7 м [5, с. 7]. меж х ьвівської обл. н лічують 168 родовищ торфу, площ промислової глибини яких ст новить 48123 г [1, с. 8]. йбільшими торфовищ ми, площею пон д 500 г , є Сп сівське, дехівське, еликі болот , оп тинське т ін. (т бл. 1).

( 
йбільші (>500 г ) торфовищ

ьвівської обл. т їхні головні х р ктеристики [1-3]

\begin{tabular}{|c|c|c|c|c|c|c|c|c|}
\hline \multirow[b]{2}{*}{ зв } & \multirow{2}{*}{$\begin{array}{c}\text { г ль- } \\
\text { н } \\
\text { площ , } \\
\text { г }\end{array}$} & \multicolumn{2}{|c|}{ либин , м } & \multirow{2}{*}{$\begin{array}{c}\text { оль- } \\
\text { ність } \\
\text { с } \\
\%\end{array}$} & \multirow{2}{*}{$\begin{array}{c}\text { тупінь } \\
\text { розкл ду } \\
\text { R, \% }\end{array}$} & \multirow{2}{*}{$\begin{array}{c}\text { риродн } \\
\text { вологість } \\
\mathrm{W}, \%\end{array}$} & \multirow{2}{*}{$\begin{array}{c}\text { ктивн } \\
\text { кислот- } \\
\text { ність, } \\
\text { р }\end{array}$} & \multirow{2}{*}{$\begin{array}{l}\text { міст } \\
\%\end{array}$} \\
\hline & & $\begin{array}{l}\text { кси- } \\
\text { м льн }\end{array}$ & ередня & & & & & \\
\hline П сівське & 14742 & 8,9 & 3,40 & 28,0 & 30 & 83,0 & 7,30 & 3,95 \\
\hline олокія & 3881 & 4,5 & 1,54 & 21,5 & 42 & 82,2 & 6,00 & 4,77 \\
\hline олотня & 800 & 3,3 & 1,76 & 13,6 & 23 & - & 5,50 & 1,87 \\
\hline озж лів & 518 & 4,6 & 1,83 & 30,6 & 35 & 83,4 & 7,40 & 14,40 \\
\hline тоянів & 4138 & 11,0 & 4,37 & 14,7 & 23 & 89,5 & - & - \\
\hline ілостоківське & 971 & 3,8 & 1,71 & 21,4 & 37 & 83,9 & 7,10 & 7,53 \\
\hline дехівське & 1646 & 6,8 & 2,73 & 19,9 & 36 & 85,6 & 6,47 & 11,80 \\
\hline дня & 688 & 5,7 & 2,21 & 21,4 & 40 & 85,8 & 7,41 & 20,00 \\
\hline глядів & 700 & - & 2,40 & 26,0 & 35 & - & - & - \\
\hline $\begin{array}{l}\text { оп тин- } \\
\text { стрівське }\end{array}$ & 774 & 6,0 & 3,20 & 20,4 & 38 & 85,9 & 6,98 & 10,71 \\
\hline олоничк & 1566 & 5,8 & 2,36 & 11,8 & 43 & 86,3 & 6,40 & 10,00 \\
\hline 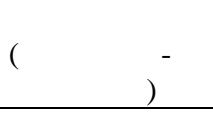 & 2226 & 6,4 & 4,13 & 14,8 & 34 & 84,2 & 3,36 & 4,15 \\
\hline ідилів & 946 & 5,3 & 2,17 & 57,4 & 42 & 75,7 & 7,34 & 12,78 \\
\hline ричівське & 609 & 3,2 & 1,15 & 23,6 & 35 & 82,0 & 6,26 & 6,56 \\
\hline ниж & 767 & 4,1 & 1,46 & 22,4 & 32 & 85,8 & 6,30 & 3,97 \\
\hline ешнівське & 2816 & 4,6 & 1,89 & 28,4 & 38 & 84,7 & 5,93 & 6,64 \\
\hline омірки & 1054 & 5,0 & 2,02 & 66,0 & 37 & 67,1 & 5,66 & 2,46 \\
\hline мільненське & 2036 & 7,2 & 2,32 & 23,0 & 38 & 85,2 & 6,11 & 8,38 \\
\hline $\begin{array}{l}\text { уб'є- } \\
\text { олосковичі }\end{array}$ & 543 & 7,6 & 2,90 & 30,1 & 32 & 86,9 & 7,40 & 30,90 \\
\hline $\begin{array}{l}\text { лесько- } \\
\text { в тів }\end{array}$ & 660 & 6,1 & 2,88 & 21,3 & 41 & 84,5 & - & - \\
\hline $\begin{array}{l}\text { ерещиця- } \\
\text { нівське }\end{array}$ & 1885 & 5,2 & 2,14 & 26,8 & 31 & 85,5 & 5,58 & 4,60 \\
\hline еченія & 617 & 2,3 & 1,29 & 20,6 & 32 & 82,7 & 6,80 & 4,76 \\
\hline оморянське & 630 & 8,8 & 2,43 & 50,2 & 39 & 83,7 & 7,40 & 7,24 \\
\hline $\begin{array}{l}\text { оріччя i } \\
\text { ерляни }\end{array}$ & 786 & 4,7 & 1,40 & 29,0 & 36 & 80,8 & - & 4,06 \\
\hline $\begin{array}{l}\text { мбір- } \\
\text { p йський }\end{array}$ & 580 & 5,2 & 1,90 & 32,4 & 32 & 81,2 & 6,58 & 2,65 \\
\hline еликі олот & 11580 & 7,9 & 2,64 & 29,1 & 36 & 90,0 & 5,80 & 1,88 \\
\hline оберк & 500 & 3,9 & 2,23 & 48,0 & 33 & 81,4 & 7,10 & 5,24 \\
\hline $\begin{array}{l}\text { 3 пл в х } \\
\text { річок ністер, } \\
\text { исмениця і } \\
\text { рудниця }\end{array}$ & 851 & 6,1 & 2,15 & 31,8 & 44 & 81,9 & 5,50 & 2,63 \\
\hline
\end{tabular}


господ рським зн ченням з п си родовищ торфу поділяють н дві групи:

- $\sigma$ л нсові - це ті з п си, використ ння яких економічно вигідне сьогодні і які з довольняють промислові вимоги як $з$ якістю сировини, т к і з гірничо-технічними умов ми експлу т ції;

- поз б л нсові (неконденційні) - це ті з п си, використ ння яких у суч сних умов х економічно невигідне через м лу потужність пл стів, низький вміст цінного компонент , скл дність умов експлу т ції.

п си торфів підтверджують н земними розвідк ми різних ст дій: пошуковою, попередньою, дет льною, т різними вид ми досліджень - геологічними, бот нічними, гідромеліор тивними тощо.

еологічні з п си торфу у меж х ьвівської обл. ст новлять 200067 тис. т, у тім числі б л нсові - 78408 тис. т, поз б л нсові-121 659 тис. т. 2008 р. дет льною розвідкою було охоплено $53 \%$ торфових родовищ, попередньою - $23 \%$, пошуково-оціночною - $24 \%$. тже, н йбільші з п си торфу (площею пон д 1000 г ) зосереджені в меж х великих торфовищ обл сті, які розміщені в північних і північно-східних $\mathrm{p}$ йон х регіону, зокрем , у долин х річок олокія, тир, т кож н півдні - у долині $\mathrm{p}$. ністер [1, с. 3]. г лом торфи досліджув ної території предст влені головно низинним i, менше, перехідним типом покл ду.

дним із основних якісних пок зників торфового покл ду є ступінь його розкл д ння. исок зольність і низький пок зник розкл д ння торфу знижують його теплотворну зд тність. тупінь розкл д ння торфів ьвівської обл. середньо ст новить 25$30 \%$. р пляються торфовищ зі ступенем розкл д ння пон д $60 \%$, т кож менше $20 \%$. г лом н йпоширенішими є торфовищ із зольністю торфу близько $50 \%$, зн чно менш їх кількість з зольністю торфу пон д 70 \% і незн чно поширені торфовищ 3 зольністю торфу до $20 \%$. зн чимо, що ділянки торфових покл дів із зольністю торфу пон д $25 \%$ можн використовув ти для видобув ння торфу н добриво. еплотворн зд тність торфів, як вз ємопов'яз н зі ступенем розкл ду з різної зольності, ст новить середньо для м лорозкл деного торфу 4800 к л, середньорозкл деного - 5300 к л, для добре розкл деного - 5800 к л [5, с. 45].

еріод інтенсивного торфовидобув ння н території обл сті прип д в н 60-80-ті роки XX ст. ро це свідчить дин мік видобутку торфу в меж х н йбільших торфовищ - оп тинського і тоянівського (рис. 1). тоянівське родовище розт шов не н півдні p йону у верхів'ї р. удилівки. ого площ ст новить 3712,5 г, середня глибин -

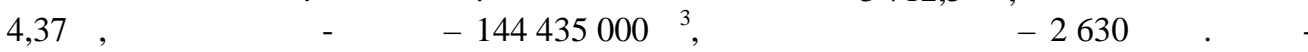
тинське родовище розміщене в долині річок стрівки і тиру. ого площ -625 г,

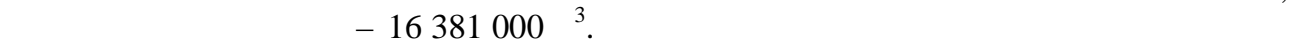
меж $\mathrm{x}$ тоянівського і оп тинського родовищ свідч ть, що, почин ючи з середини 90-х років ст. видобув ння торфу різко зменшилося у цих двох основних торфовищ х т повністю припинилося у всіх інших торфовищ х обл сті.

лежно від ступеня розкл ду, кислотності, вмісту орг нічних т мінер льних речовин із торфу виготовляють різні види торфокомпостів, торфо мі чні гумінові добрив , з стосовують його н підстилку тощо. н чні резерви сировини для орг но-мінер льних добрив є у торфовищ лого олісся і ередк рп ття. крім того, м лорозкл дений торф - це цінн підстилк для худоби і птиці, ним з сип ють гноївку, вн слідок чого утворюється цінний торфогній. г лом близько 60 \% видобутого торфу використовують як добриво, субстр т для г зонів і підстилку. кож виробляють торфові горщики для вирощув ння розс ди, торфомінер льно мі чні добрив рогрес, грунт по- 
живний, торфові біодобрив он к, добрив осток, торфопослідні добрив онкурент, торф ф сов ний для с дівників. орф т кож слугує сировиною для хімічної переробки в етиловий спирт, гумінові кислоти, фурфурол, віск, для вирощув ння кормових дріжджів тощо.

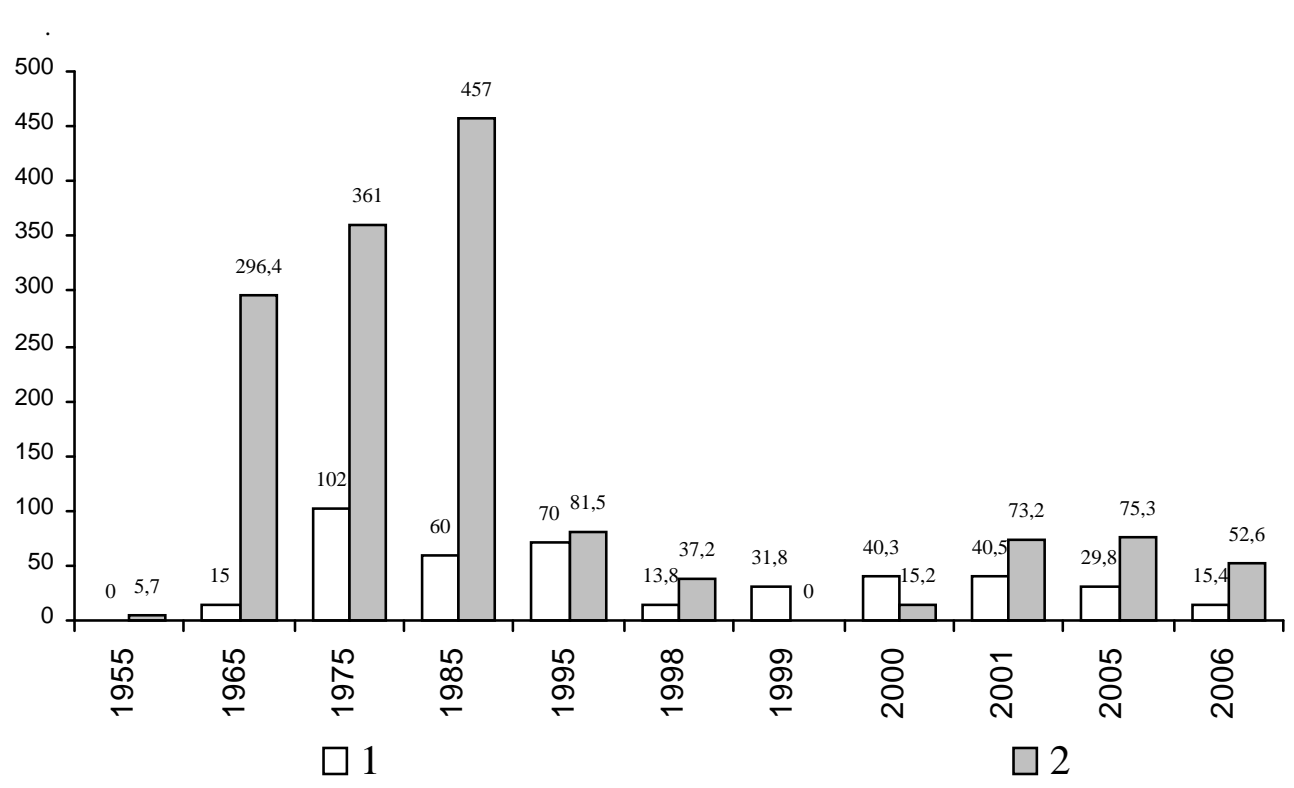

ис. 1. ин мік видобув ння торфу в меж х оп тинського (1) і тоянівського (2) торфовищ ьвівської обл. [1, с. 26; 2].

н слідок інтенсивної експлу т ції торфових родовищ у минулому, сьогодні н території ьвівської обл. н лічують п’ять ділянок із виробленими з п с ми торфу (т бл. 2) і 12 торфовищ (з г льною площею 1081 г ), де под льше добув ння торфу є неможливим. і ділянки з йняті сільськогоспод рськими угіддями.

ідпр цьов ні торфовищ необхідно рен тур лізув ти. ен тур ліз ція може бути успішною т ефективною з умови їх рекультив ції з використ нням під природні кормові культури тощо.

ля торфового виробництв х р ктерні висок енергоємність, в жкі умови пр ці, пожежонебезпечність і з лежність від гірничо-геологічних і погодних умов. ніше торф видобув ли головно підприємств кр їнського концерну торфової промисловості крторф, який з 2007 р. не пр цює.

уч сне використ ння покл дів торфу економічно невигідне т недост тньо ефективне. н чні площі осушених торфових родовищ використовують для вирощув ння прос пних культур, що спричиняє зн чні втр ти орг нічної м си вн слідок її мінер лі3 ції т вітрової ерозії (дефляції). рім того, торфовидобув ння для отрим ння енергетичного торфового п лив у меж х ьвівської обл. т кож нер ціон льне і неефективне. ід ч с посушливих років літнього періоду торфи ч сто с моз йм ються. прикл д, у 2000 р. $з$ фіксов но пожежі н торфовищ х площею 66,2 г , 2002 р. - н 73,7 г . ещо 
менш площ торфовищ горіл у 2001 р. - 0,44 г . 2006 р. пожежі н торфовищ х спостеріг ли н площі 57,4 г , в 2007-2009 рр., відповідно, - 10,4, 1,3, і 11,2 г (з д ними іністерств н дзвич йних ситу цій у ьвівській обл.). 2009 р. н йч стіше пожежі були н півночі ьвівської обл., зокрем , у меж х лого олісся (т бл. 3 ). ку різницю у кількості т площі з горяння торфовищ з ост нні десять років можн пояснити клім тичними особливостями кожного року. окрем , 2001, 2007, 2008 т 2009 рр. були дост тньо вологими (середньорічн кількість оп дів ст новил близько $1000 \mathrm{Mm})$.

блиця 2

ілянки з виробленими з п с ми торфу [1, с. 863]

\begin{tabular}{|c|c|c|c|c|}
\hline $\begin{array}{c}\text { орфове родовище т } \\
\text { ділянк }\end{array}$ & \begin{tabular}{c}
\multicolumn{1}{c}{ лощ } \\
виробленої \\
ділянки, г
\end{tabular} & $\begin{array}{l}\text { ироблені } \\
\text { з п си } \\
\text { торфу, } \\
\text { тис. т } \\
\end{array}$ & $\begin{array}{c}\text { дміні- } \\
\text { стр тив- } \\
\text { ний р йон }\end{array}$ & $\begin{array}{c}\text { т н } \\
\text { використ ння } \\
\text { торфовищ }\end{array}$ \\
\hline $\begin{array}{l}\text { ілостоківське: } \\
\text { ділянки н південний з хід } \\
\text { від с. ушне т н д від } \\
\text { с. т нин }\end{array}$ & 108 & 597 & $\begin{array}{l}\text { дехів- } \\
\text { ский }\end{array}$ & $\begin{array}{l}\text { озробляли к р'єрним } \\
\text { способом, з топлене } \\
\text { водою }\end{array}$ \\
\hline $\begin{array}{ll}\text { орошів: } & \\
\text { ділянк } & \text { лий } \text { орошів }\end{array}$ & 35 & 210 & $\begin{array}{l}\text { овків- } \\
\text { ський }\end{array}$ & $\begin{array}{l}\text { озробляли } \\
\text { фрезерним способом, } \\
\text { с/г угіддя }\end{array}$ \\
\hline $\begin{array}{l}\text { оріччя і ерляни: } \\
\text { ділянк юбінь еликий }\end{array}$ & 84 & 297 & $\begin{array}{l}\text { ородоць- } \\
\text { кий }\end{array}$ & $\begin{array}{l}\text { озробляли } \\
\text { фрезерним способом, } \\
\text { с/г угіддя }\end{array}$ \\
\hline $\begin{array}{l}\text { трутин : } \\
\text { ділянк н північ від } \\
\text { с. трутин }\end{array}$ & 14 & 199 & $\begin{array}{l}\text { олочів- } \\
\text { ський }\end{array}$ & $\begin{array}{l}\text { озробляли } \\
\text { фрезерним способом, } \\
\text { с/г угіддя }\end{array}$ \\
\hline оп тин- стрівське & 427 & 2538 & $\begin{array}{l}\text { дехів- } \\
\text { ський }\end{array}$ & $\begin{array}{l}\text { озробляли різними } \\
\text { способ ми, с/г угіддя } \\
\text { т } 3 \text { топлені к р'єри }\end{array}$ \\
\hline сього & 668 & 3841 & & \\
\hline
\end{tabular}

блиця 3

оріння торфовищ лого олісся

(з д ними іністерств н дзвич йних ситу цій у ьвівській обл., 2009 р.)

\begin{tabular}{|c|c|l|}
\hline лощ горіння торфу, г & ількість виїздів & \multicolumn{2}{|c|}{ йон } \\
\hline 0,85 & 4 & с. ясн - уськ овківського p-ну \\
\hline 0,03 & 1 & с. орниськ овківського р-ну \\
\hline 0,03 & 1 & с. рибовичі овківського p-ну \\
\hline 0,05 & 1 & с. овдури родівського йону \\
\hline 0,04 & 1 & с. оп тин дехівського р-ну \\
\hline 0,013 & 1 & с. ш н ородоцького p-ну \\
\hline 0,35 & 1 & с. яглів ок льського р-ну \\
\hline
\end{tabular}

иту ція ускл днен ще тим, що сьогодні не проводять інвент риз ції т контролю 3 ст ном функціонув ння родовищ торфу. меж х торфовищ ч сто можн спостеріг - 
ти нес нкціонов не добув ння торфу. ільшість родовищ потребує проведення рекультив ційних робіт із з зн ченням типу використ ння. прикл д, у меж х тоянівського торфовищ 3 ост нні п’ять років рекультив цією було охоплено всього 20 г . ещо кр щ ситу ція в меж $\mathrm{x}$ оп тинського торфовищ . ут щороку рекультивують приблизно 10-15 г його площі. крім того, зн чні площі ділянок торфових боліт використовують під сільськогоспод рські (ріллю) т кормові (п совищ, сінож ті) угіддя. н слідок переосушення продуктивність кормових угідь зн чно погіршен , вони дегр дують, інтенсивно з рост ють син нтропними вид ми рослин.

тже, н території ьвівської обл. є зн чні з п си торфових ресурсів. фіційно торф добув ють тільки у меж х двох великих торфовищ - тоянівського т оп тинського. ого використовують як добриво, субстр т для г зонів і підстилку. еред головних проблем торфодобувної г лузі н звемо т кі: нес нкціонов не добув ння торфу, с моз горяння торфополів у посушливі періоди року, відсутність коштів н проведення рекультив ційних робіт. ому н ч сі орг ніз ція менеджменту р ціон льного торфовикорист ння т з безпечення охорони болотних комплексів ьвівської обл.

1. ерж вний 6 л нс $з$ п сів корисних коп лин кр їни. орф. ьвівськ обл сть (н 01.01.2003 р.). н. 7 / укл д. : . . льськ , . . йчук. - ип. 92. - . : ерж вне н уково-виробниче підприємство ерж вний інформ ційний геологічний фонд кр їни еоінформ кр їни, 2003.-103 с. 2. ерж вний 6 л нс з п сів корисних коп лин кр їни. орф. (н 01.01 .2007 р.). н. 1 / укл д. : . . льськ , . . йчук. - ип. 92. - . : ерж вне н уково-виробниче підприємство ерж вний інформ ційний геологічний фонд кр їни еоінформ кр їни, 2007.-89 с.

3. рт торфових ресурсів кр їни 1:500 000 / укл д. : . . ілобловськ, . . ст шій. ерж вн геологічн служб івнічгеологія, 2000.

4. иштв н. . овременные проблемы в обл сти р цион льного использов ния и охр ны торфяных месторождений / . . иштв н, . . новицкий // нтропогенные изменение, охр н р стительности болот и прилег ющих территорий. - инск : ук и техник , 1981. - .28-37.

5. пр вочник по торфу / под ред. к нд. техн. н ук . . 3 рев и д-р техн. н ук . . орчунов .- . : едр , 1982. -760 с.

6. орфово-болотний фонд , його р йонув ння т використ ння / . . p діс, . . узьмичов, . . ндрієнко т ін. - . : ук. думк , 1973. - 264 с.

m ття: н дійшл до редколегії 04.09.2011

прийнят до друку 20.09.2011

\section{ANALYSIS OF THE USE OF PEAT RESOURCES OF THE LVIV REGION}

\section{N. Blazhko, F. Kiptach}

Ivan Franko National University of Lviv, . Doroshenko St., 41, UA - 79000 Lviv, Ukraine

The analysis of stocks of peat resources of the Lviv Region and the main characteristics of peat is presented. It is shown the dynamic extraction of peat within the main peat area. The main problems associated with the extraction of peat and its rational use are characterised and the solutions are offered to these problems.

Key words: peat, peat deposits, worked peat, peat renaturalization. 


\section{• л жко, • ипт ч \\ ввовский н иион льный университет имени в н рнко, \\ ул. . орошенко, 41, г. ьвов, 79000, кр ин}

ро н лизиров но з п сы торфяных ресурсов ьвовской обл., т кже основные морфометрические х р ктеристики торфов. тр жено дин мику объемов добычи торф в предел х крупнейших торфяников обл сти. к з но гл вные проблемы, связ нные с добычей торф , и предложены пути решения этих проблем.

лючевые слов : торф, торфяные месторождения, отр бот нные торфяники, рен тур лиз ции торфяников. 